\title{
NUTRITIONALLY DESIRABLE FATTY ACIDS INCLUDING CLA OF COW'S MILK FAT EXPLAINED BY ANIMAL AND FEED FACTORS
}

\author{
Robert Kala ${ }^{1}$, Eva Samkovál ${ }^{1}$ Jana Koubovál, Lucie Hasoňovál,

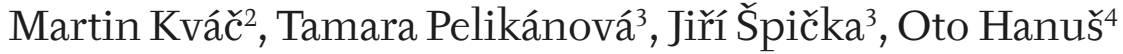

\begin{abstract}
${ }^{1}$ Department of Food Biotechnology and Agricultural Products Quality, Faculty of Agriculture, University of South Bohemia, Branisovska 1645/31a, 37005 Ceske Budejovice, Czech Republic

${ }^{2}$ Department of Animal Husbandry Sciences, Faculty of Agriculture, University of South Bohemia, Branisovska 1645/31a, 37005 Ceske Budejovice, Czech Republic

32Department of Applied Chemistry, Faculty of Agriculture, University of South Bohemia, Branisovska 1645/31a, 37005 Ceske Budejovice, Czech Republic

${ }^{4}$ Dairy Research Institute, Ltd., Ke Dvoru 791/12a, 16000 Prague, Czech Republic
\end{abstract}

\begin{abstract}
KALA ROBERT, SAMKOVÁ EVA, KOUBOVÁ JANA, HASOŇOVÁ LUCIE, KVÁČ MARTIN, PELIKÁNOVÁ TAMARA, ŠPIČKA JIŘÍ, HANUŠ OTO. 2018. Nutritionally Desirable Fatty Acids Including Cla of Cow'S Milk Fat Explained by Animal and Feed Factors. Acta Universitatis Agriculturae et Silviculturae Mendelianae Brunensis, 66(1): 69-76.

This study evaluated the effects of four factors (breed, parity, month of lactation and feeding ration) on the total explained variation $\left(\mathrm{R}^{2}\right)$ determining composition of nutritionally important fatty acids. Individual milk samples were collected four times over an entire year (March, June, September, and December, respectively) on a conventional farm from two breeds: Czech Fleckvieh (dual-purpose, local) and Holstein (dairy, worldwide). In total, 145 samples (36; 38; 35 and 36, respectively) were analysed. Within the $\mathrm{R}^{2}$, feeding ration and month of lactation were the main factors affecting milk fatty acids composition, whereas breed and parity showed a low effect. A high percentage of the $\mathrm{R}^{2}$ was observed in rumenic acid (52\%), for example, whereas a low percentage was observed in both palmitic acid (30\%) and oleic acid (30\%). This may be due to intra-breed variability affected by different genetic predisposition of each cows, their performance or individual response to changes in feeding ration.
\end{abstract}

Keywords: cows, milk fatty acid, rumenic acid, breed, lactation, feeding ration

\section{INTRODUCTION}

Most of unsaturated fatty acids (FA) are more desirable in human nutrition than their saturated counterparts. The former group is subdivided into mono- and polyunsaturated FA. Moreover, polyunsaturated FA are nutritionally classified as n-6 and n-3 groups, according to the position of first double bond, numbered from the methyl end of carbon chain. The major unsaturated FA are non-essential oleic acid (18:1 cis-9) and essential linoleic (18:2 n-6) and alpha-linolenic acids (18:3 n-3), which have all-cis double bonds (Jensen, 2002).
Conjugated linoleic acid (CLA) is a group term for a series of conjugated dienoic positional and geometrical isomers of linoleic acid, which are relatively more abundant in the milk and fat tissue of ruminants (Dhiman et al., 2005). In CLA, the most important isomer is cis-9, trans-11-linoleic acid (RA, rumenic acid). It forms about $75-90 \%$ of all CLA isomers (Kramer et al., 1998) and has putative health benefit (Palmquist et al., 2005). RA in milk fat is primarily biosynthesized from monounsaturated vaccenic acid (18:1 trans-11) by the activity of the enzyme $\Delta$ 9-desaturase in mammary gland. According to Mosley et al. (2006), this pathway 
produces about $80 \%$ of RA. The health effects of individual CLA isomers have been studied since the 1980s. RA has been associated with the prevention of a number of diseases, including cardiovascular diseases, obesity and diabetes (e.g. Riediger et al., 2009; Sailas and Spener, 2009). However, most of the positive effects of CLAs have been observed in animals, and the evidence from clinical studies in humans is less convincing (Gebauer et al., 2007; Yang et al., 2015).

The fatty acid composition of bovine milk fat is affected by animal factors (Samkova et al., 2012; Schwendel et al., 2015) and feed factors (Chilliard et al., 2001; Elgersma, 2015). For FA with up to 16 carbons, animal factors are expected to have a greater effect due to moderate coefficients of

I: Distribution of milk samples according to breed, parity and month of lactation.

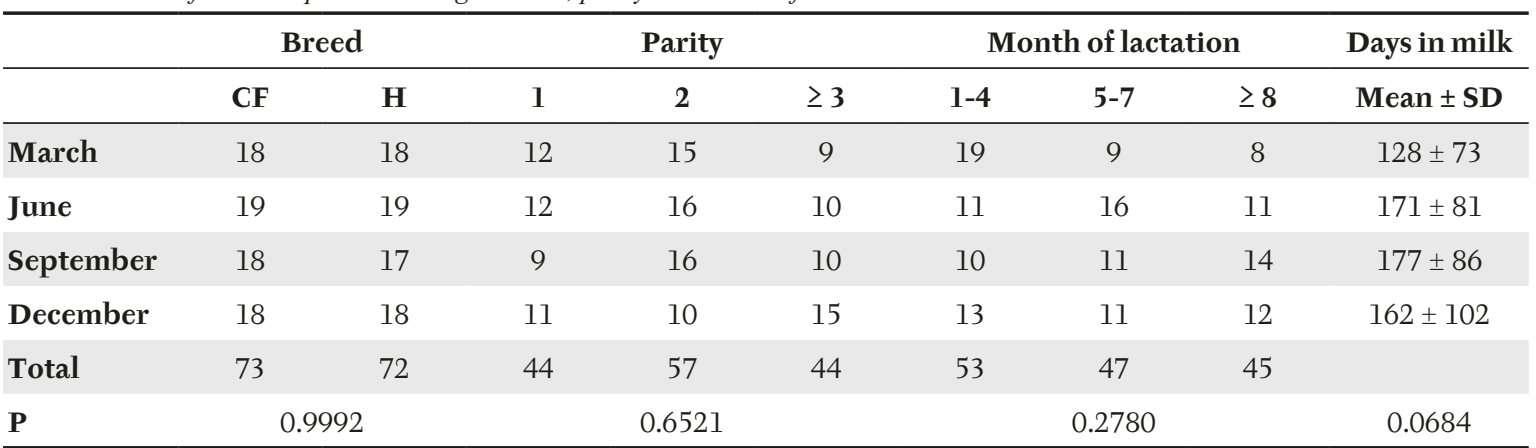

$P=$ probability, $\chi^{2}$ for breed, parity and month of lactation, $\mathrm{SD}=$ standard deviation,

CF = Czech Fleckvieh, H = Holstein, Month of lactation: 1-4 (10-120 days in milk), 5-7 (121-210), 8-10 (211-345).

II: Intake of matter, ingredient and chemical composition of feeding rations.

\begin{tabular}{|c|c|c|c|c|}
\hline Item & March & June & September & December \\
\hline \multicolumn{5}{|l|}{ Intake (kg/day) } \\
\hline Fresh matter & 34.4 & 35.3 & 34.1 & 36.5 \\
\hline Dry matter (DM) & 17.5 & 16.5 & 15.8 & 17.9 \\
\hline \multicolumn{5}{|l|}{ Ingredient composition (\% of DM) } \\
\hline Grass silage & 24.5 & 22.2 & 21.6 & 26.8 \\
\hline CCM (corn cob meal silage) & - & - & - & 12.4 \\
\hline Fresh lucerne (Medicago sativa) & - & 11.4 & - & - \\
\hline Fresh maize & - & - & 18.4 & - \\
\hline Production feed mixture (PM) & 27.9 & 32.5 & 31.1 & 19.8 \\
\hline Minerals and vitamins mixture (MM) & 1.1 & 1.1 & 1.2 & 1.0 \\
\hline \multicolumn{5}{|l|}{ Chemical composition } \\
\hline DM (g) & 443 & 399 & 400 & 441 \\
\hline CP (g/kg of DM) & 146 & 160 & 153 & 146 \\
\hline $\mathbf{n X P}$ & 147 & 151 & 150 & 146 \\
\hline
\end{tabular}

PM = mixture consisted of 20 (32; 9), 20 (37; 30), $12(0 ; 0), 0(0 ; 14), 20(28 ; 7), 25(0 ; 37)$ and $3(3 ; 3) \%(w / w)$ of barley, wheat, oats, lupin (Lupinus albus), extracted soybean meal, extracted rapeseed meal, and a mixture of minerals and vitamins in March (June - September; December), MM = mixture consisted per kg:210, 30, 100, $70 \mathrm{~g}$ of calcium, phosphorus, sodium, magnesium, respectively; 750, 30, 80, 2,730 mg of copper, selenium, iodine, vitamin E, respectively; 500,000 and 75,000 IU of vitamin $\mathrm{A}$ and $\mathrm{D}_{3}$, respectively, $\mathrm{CP}=\mathrm{N} \times 6.25, \mathrm{nXP}=$ protein utilised in the intestine (DLG-Futterwerttabellen, 1997), $\mathrm{NE}_{\mathrm{L}}=$ net energy for lactation (Sommer et al., 1994). 
heritability (Schennink et al., 2008; Stoop et al., 2008). Conversely, feed factors have the greatest effect when the carbon chain length is greater than 18 (Samkova et al., 2014). For instance, CLA content can vary between 0.34 and $3.08 \%$ of total FA depending especially on feeding (Dhiman et al., 2005; Elgersma, 2015). The highest levels are observed under feeding with fresh forage (Collomb et al., 2002), whereas breed and parity show lower effects (Stanton et al., 1997).

Our work aimed at evaluating the extent of variability of four factors (breed, parity, month of lactation and feeding ration) affecting proportions of nutritionally desirable FA including RA in milk fat of dairy cows reared under farm management practices that are typical in the Czech Republic.

\section{MATERIALS AND METHODS}

Ethical committee hereby declares that experiments performed in the present study are according Act No 246/1992 Coll., on the protection of animals against cruelty of the Czech Republic. With regard to the type of study, no special permission is needed.

The study was carried out on a farm (420 meters above sea level), in the region of South Bohemia, Czech Republic. On the farm, cows of two breeds, Czech Fleckvieh (dual-purpose, local) and Holstein (dairy, worldwide) were housed together and milked twice a day. Individual milk samples were collected within the afternoon regular testing of milk efficiency in each of four months: March, June, September and December. Milk samples were taken with regard to breed, parity and month of lactation to obtain a balanced set of samples (Tab. I).

All cows were fed under the same conditions. Total mixed rations were formulated according to the German recommendations for ruminant feeding (DLG-Futterwerttabellen, 1997) and calculated for a mean live weight of $650 \mathrm{~kg}$, milk fat content of $4.2 \%$ and milk protein content of $3.5 \%$. Total mixed rations consisted of components widely used in the recent Czech farming practice (Tab. II). All feeding rations were fed at least for three weeks before sampling.

Milk samples were cooled $\left(6^{\circ} \mathrm{C}\right)$ immediately after collection and transported to the laboratory in a cool box. Fat, protein and lactose contents were determined spectrophotometrically using a MilcoScan 4000 apparatus (Foss Electric, Hillerød,
Denmark). This instrument was regularly calibrated according to results of relevant reference methods (for fat content according to Roese-Gottlieb method, for crude protein content according to Kjeldahl method a for lactose monohydrate content according to polarimetric method) and took part in proficiency testing with good results. This was carried out in accordance with instrument operation manual. Milk fat was extracted with petroleum ether from freeze-dried milk samples. FA in isolated fat were reesterified to their methyl esters with a methanolic solution of potassium hydroxide. Methyl esters of FA were determined by a gas chromatographic method (GLC) using a Varian 3300 apparatus (Varian Techtron, USA) under conditions described in Tab. III.

The identification of FA was carried out using analytical standards (Supelco, USA). In total, 64 FA were observed, 50 of which were identified. The proportions of individual FA were calculated from the ratio of their peak area to the total area of all the observed FA.

Data were analysed by the program Statistica CZ 12 (Statsoft CR) using a general linear model with fixed effects of breed, parity, month of lactation and feeding ration:

$$
Y_{i j k l}=\mu+B_{i}+P_{j}+M O L_{k}+F_{1}+\varepsilon_{i j k l}
$$

where:

$Y_{\mathrm{ijkl}}=$ dependent variables: milk yield $(\mathrm{kg} / \mathrm{d})$; fat, protein and lactose content (g/100 g); proportion of individual milk FA $(\mathrm{g} / \mathrm{l} / \mathrm{g} \mathrm{g}$ of total FA); and groups of FA ( $\mathrm{g} / 100 \mathrm{~g}$ of total FA), $\mu=$ mean,

$\mathrm{B}_{\mathrm{i}}=$ breed $(\mathrm{i}=$ Czech Fleckvieh, Holstein $)$,

$\mathrm{P}_{\mathrm{j}}=$ parity $(\mathrm{j}=1,2, \geq 3)$,

$\mathrm{MOL}_{\mathrm{k}}=$ months of lactation ( $\mathrm{k}=<30$ days in milk

(1); 31-60 (2); 61-90 (3); 91-120 (4); 121-150 (5);

$151-180$ (6); 181-210 (7); 211-240 (8); 241-270 (9); $>271(10)$,

$\mathrm{F}_{1}=$ feeding ration $(\mathrm{l}=$ March, June, September and December),

$\varepsilon_{\mathrm{ijkl}}=$ residual error.

Tukey HSD test for unequal $\mathrm{N}$ was used for group comparisons (post hoc test).

Total explained variation $\left(\mathrm{R}^{2}\right.$, coefficient of determination) and variation explained by

III: Parameters of chromatographic analysis of fatty acids.

\begin{tabular}{lcc}
\hline \multicolumn{1}{c}{ Parameter } & Value \\
\hline $\begin{array}{l}\text { Column } \\
\text { Detector }\end{array}$ & Column & $55^{\circ} \mathrm{C}$ for $5 \mathrm{~min}, 40^{\circ} \mathrm{C} / \mathrm{min}$ up to $170{ }^{\circ} \mathrm{C}, 2.0^{\circ} \mathrm{C} / \mathrm{min}$ up to $196^{\circ} \mathrm{C}, 10.0^{\circ} \mathrm{C} / \mathrm{min}$ up to $210^{\circ} \mathrm{C}$ \\
& $250^{\circ} \mathrm{C}$ \\
Temperature & injection & $250^{\circ} \mathrm{C}$ \\
& detector & $1.8 \mathrm{ml} / \mathrm{min}$ \\
Helium flow & $1 \mu \mathrm{l}, \mathrm{split} 10$ \\
\hline Injection &
\end{tabular}


individual effects (factors variation) were calculated using sum of squares and were expressed as a percentage. $\mathrm{R}^{2}$ was defined as [(1-(residual sum of squares/total sum of squares)).100]. Factor variation was defined as [(sum of squares of individual effects/total sum of squares).100].

\section{RESULTS AND DISCUSSION}

A general linear model, comprising breed, parity, month of lactation and feeding ration, was used to evaluate the variability of selected FA of bovine milk fat, groups of FA and their mutual relations. Using this model, the highest levels of $\mathrm{R}^{2}$ were $65 \%$ and $52 \%$ for vaccenic acid and RA, respectively (Tab. IV). Within the observed groups, the value of $\mathrm{R}^{2}$ for branched-chain FA was $54 \%$. The high $\mathrm{R}^{2}$ of selected FA were due, in particular, to high variability in feeding ration, with the exception of branched chain FA, where the value of $\mathrm{R}^{2}$ was primarily affected by the variability in month of lactation. The major contribution of month of lactation to the $\mathrm{R}^{2}$ in animal factors was previously reported by Kelsey et al. (2003).

Even though our work was carried out under common farm management conditions, we observed a significant effect of feeding ration on the $\mathrm{R}^{2}$. A comparable effect was reported from exact feeding experiments (e.g. Leiber et al., 2005; Wiking et al., 2010).

The high explained variation in vaccenic acid and $\mathrm{RA}$, as affected by the feeding ration, is probably due to feeding with fresh forage, lucerne and maize. However, previous studies found that, compared to grazing (Elgersma, 2015) or organic farming conditions (O'Donnell et al., 2010), partial feeding of housed dairy cows with fresh forage had only a limited effect on the proportion of nutritionally desirable FA in milk fat (Leiber et al., 2005). This could explain the low level of variation in oleic acid (6\%) and the group of monounsaturated FA (5\%). The higher level of explained variation in n-3 polyunsaturated FA (32\%), compared to the n-6 polyunsaturated FA group (25\%), was probably

IV: Distribution of total explained variation (R2) for milk yield ( $\mathrm{kg} / \mathrm{d}$ ), fat, protein and lactose content (g/100 $\mathrm{g}$ ), fat corrected milk (FCM $4.0)$ and energy corrected milk (ECM) ( $\mathrm{kg} / \mathrm{d})$, individual fatty acids (FA), and groups of $F A(\mathrm{~g} / 100 \mathrm{~g}$ of $F A)$ in general linear model involving animal and feed factors.

\begin{tabular}{|c|c|c|c|c|c|c|c|c|c|c|}
\hline & \multicolumn{8}{|c|}{ Factors variation $^{1}$} & \multirow{2}{*}{\multicolumn{2}{|c|}{$\mathbf{R}^{2}$}} \\
\hline & \multicolumn{2}{|c|}{ Breed } & \multicolumn{2}{|c|}{ Parity } & \multicolumn{2}{|c|}{$\begin{array}{l}\text { Month of } \\
\text { lactation }\end{array}$} & \multicolumn{2}{|c|}{ Feeding ration } & & \\
\hline & $\%$ & $\mathbf{P}$ & $\%$ & $\mathbf{P}$ & $\%$ & $\mathbf{P}$ & $\%$ & $\mathbf{P}$ & $\%$ & $\mathbf{P}$ \\
\hline \multicolumn{11}{|c|}{ Milk yield and composition } \\
\hline Milk yield & 5 & $* * *$ & 2 & $t$ & 37 & $* * *$ & 1 & ns & 45 & $* * *$ \\
\hline Fat content & 1 & ns & $0^{*}$ & ns & 12 & $*$ & 22 & $* * *$ & 35 & $* * *$ \\
\hline Protein content & 3 & $*$ & 1 & ns & 32 & $* * *$ & 4 & + & 39 & $* * *$ \\
\hline Lactose content & $0^{\#}$ & ns & 3 & $t$ & 31 & $* * *$ & 1 & ns & 35 & $* * *$ \\
\hline FCM 4.0 & 4 & $* *$ & 2 & ns & 33 & $* * *$ & 2 & ns & 41 & $* * *$ \\
\hline ECM & 4 & $* *$ & 1 & ns & 32 & $* * *$ & 2 & ns & 39 & $* * *$ \\
\hline \multicolumn{11}{|l|}{ Individual FA } \\
\hline 16:0 & 2 & $t$ & 3 & $\dagger$ & 15 & $* *$ & 10 & $* * *$ & 30 & $* * *$ \\
\hline 18:1 cis-9 & $0^{\#}$ & ns & 3 & $\dagger$ & 21 & $* * *$ & 6 & $*$ & 30 & $* * *$ \\
\hline 18:1 trans-11 & $0^{\#}$ & ns & 1 & ns & 9 & $* * *$ & 55 & $* * *$ & 65 & $* * *$ \\
\hline 18:2 n-6 & $0^{\#}$ & ns & $0^{*}$ & ns & 10 & $t$ & 15 & $* * *$ & 25 & $* * *$ \\
\hline $18: 3 n-3$ & $0^{\#}$ & ns & 1 & ns & 6 & ns & 27 & $* * *$ & 34 & $* * *$ \\
\hline 18:2 cis-9, trans-11 & 2 & $*$ & 3 & * & 7 & $*$ & 40 & $* * *$ & 52 & $* * *$ \\
\hline \multicolumn{11}{|l|}{ Group of $\mathbf{F A}^{2}$} \\
\hline C4-14 & $0^{\#}$ & ns & 3 & ns & 13 & $* *$ & 12 & $* * *$ & 28 & $* * *$ \\
\hline MUFA & $0^{\#}$ & ns & 2 & ns & 21 & $* * *$ & 5 & $*$ & 30 & $* * *$ \\
\hline BCFA & $0^{\#}$ & ns & 4 & $* *$ & 33 & $* * *$ & 17 & $* * *$ & 54 & $* * *$ \\
\hline PUFA n- 6 & $0^{\#}$ & ns & $0^{\#}$ & ns & 6 & ns & 25 & $* * *$ & 32 & $* * *$ \\
\hline PUFAn-3 & $0^{\#}$ & ns & $0^{\#}$ & ns & 6 & ns & 32 & $* * *$ & 39 & $* * *$ \\
\hline
\end{tabular}

$\mathrm{P}=$ probability, $\mathrm{ns}=$ not significant, $\mathrm{\dagger}=\mathrm{P}<0.10,{ }^{*}=\mathrm{P}<0.05,{ }^{* *}=\mathrm{P}<0.01,{ }^{* *}=\mathrm{P}<0.001$, \# $=\%$ of factors variation $<0.5 ; 1$ Factors variation = proportion (\%) of individual factors variation accounted for by $\mathrm{R} 2$ (coefficient of determination);

2 C4-14= saturated FA, even, MUFA = monounsaturated FA, cis isomers, BCFA = branched chain FA, PUFA n- 6 = polyunsaturated FA n-6, PUFA n-3 = polyunsaturated FA n-3. 
caused by feeding with fresh lucerne. According to Wiking et al. (2010) legumes have a greater effect on the $n-3$ group than the $n-6$ group.

It is also evident that different FA formation pathways have a considerable effect on factors variation. According to Bauman and Griinari (2003), FA with 4 to 14 carbons (C4-14) and about 50\% of palmitic acid (16:0) are synthesised de novo in the mammary gland, whereas FA with $\geq 18$ carbons are transported to the mammary gland from feed as unesterified FA or as preformed FA. Microbial processes in the rumen are major factors affecting odd- and branched-chain FA (Vlaeminck et al., 2006).

In our study, the contribution of feeding ration to the $\mathrm{R}^{2}$ in most of the preformed $\mathrm{FA}$ was greater than that of the three animal factors combined. For example, 18:2 n-6 15\% (feeding ration) vs. $10 \%$ (animal factors), $18: 3$ n-3 27\% vs. $7 \%$, n-6 polyunsaturated FA $25 \%$ vs. $6 \%$, and n-3 polyunsaturated FA $32 \%$ vs. $6 \%$. This contrasts with FA groups formed de novo, where animal factors contributed more to the $\mathrm{R}^{2}$ than feeding ration: for example, C4-14 group 16\% (animal factors) vs.12\% (feeding ration). This is consistent with previous works showing that coefficients of heritability are affected by the number of carbons in FA chains (Stoop et al., 2008).

In agreement with previous work, we found interbreed variability of FA in milk fat. Significant differences $(P<0.05)$ were observed in palmitic acid (30.5 and 31.7\% for Czech Fleckvieh and Holstein, respectively), or RA (0.42\% and $0.38 \%)$ - Tab. V. The differences between the breeds could be partially caused by different fat corrected milk (FCM) 19.3 and $22.0 \mathrm{~kg}$ for Czech Fleckvieh and Holstein, respectively $(P<0.05)$. Performance probably also affects differences caused by parity. Lake et al. (2007) reported differences in FA proportion particularly between multiparous and primiparous cows. Primiparous cows have a nutritionally more desirable FA composition. This was observed also

V: Milk yield, fat corrected milk (FCM 4.0) and energy corrected milk (ECM) (kg/d), fat, protein, and lactose content (g/l00 g), individual fatty acids (FA), and groups of $F A$ ( $g / 100 \mathrm{~g}$ of $F A)$ depending on breed, parity and feeding ration.

\begin{tabular}{|c|c|c|c|c|c|c|c|c|c|c|c|c|c|}
\hline \multirow{3}{*}{$\begin{array}{c}\text { Number of milk } \\
\text { samples }\end{array}$} & \multicolumn{2}{|c|}{ Breed } & \multicolumn{3}{|c|}{ Parity } & \multicolumn{4}{|c|}{ Feeding ration } & \multicolumn{4}{|c|}{ Total } \\
\hline & $\mathbf{C F}$ & $\mathbf{H}$ & 1 & 2 & $>3$ & III & VI & IX & XII & \multirow{2}{*}{ Mean } & \multirow[b]{2}{*}{ Min.-Max. } & \multirow{2}{*}{ SEM } & \multirow[b]{2}{*}{ RSD } \\
\hline & 73 & 72 & 44 & 57 & 44 & 36 & 38 & 35 & 36 & & & & \\
\hline \multicolumn{14}{|l|}{$\begin{array}{l}\text { Milk yield and } \\
\text { composition }\end{array}$} \\
\hline Milk yield & $18.7^{\mathrm{a}}$ & $22.2^{\mathrm{b}}$ & $18.8^{\mathrm{a}}$ & $19.9^{\mathrm{ab}}$ & $22.6^{\mathrm{b}}$ & $22.1^{\mathrm{b}}$ & $20.4^{\mathrm{ab}}$ & $18.0^{\mathrm{a}}$ & $21.0^{\mathrm{ab}}$ & 20.4 & $4.5-43.3$ & 0.61 & 36 \\
\hline Fat content & 4.22 & 4.02 & 4.11 & 4.20 & 4.03 & $3.58^{\mathrm{a}}$ & $4.30^{\mathrm{bc}}$ & $4.80^{c}$ & $3.77^{\mathrm{ab}}$ & 4.12 & $2.17-6.60$ & 0.07 & 21 \\
\hline Protein content & $3.62^{\mathrm{b}}$ & $3.49^{\mathrm{a}}$ & 3.57 & 3.56 & 3.53 & $3.36^{\mathrm{a}}$ & $3.61^{\mathrm{b}}$ & $3.63^{\mathrm{b}}$ & $3.62^{\mathrm{b}}$ & 3.55 & $2.51-4.74$ & 0.03 & 11 \\
\hline Lactose content & 4.78 & 4.75 & 4.84 & 4.75 & 4.73 & 4.84 & 4.76 & 4.74 & 4.73 & 4.77 & $3.30-5.40$ & 0.03 & 7 \\
\hline FCM 4.0 & $19.3^{a}$ & $22.0^{\mathrm{b}}$ & $19.1^{\mathrm{a}}$ & $20.1^{\mathrm{ab}}$ & $22.8^{\mathrm{b}}$ & 20.5 & 21.3 & 19.9 & 20.8 & 20.6 & $3.7-42.0$ & 0.58 & 33 \\
\hline ECM & $21.2^{\mathrm{a}}$ & $24.1^{\mathrm{b}}$ & $21.0^{\mathrm{a}}$ & $22.0^{\mathrm{ab}}$ & $25.0^{\mathrm{b}}$ & 22.6 & 23.2 & 21.4 & 23.3 & 22.6 & $4.1-47.0$ & 0.62 & 33 \\
\hline
\end{tabular}

$\begin{array}{lccccccccccccc}\text { Individual FA } & & & & & & & & & & & & & \\ \text { 16:0 } & 30.5^{\mathrm{a}} & 31.7^{\mathrm{b}} & 30.1 & 31.4 & 31.6 & 31.3^{\mathrm{b}} & 32.1^{\mathrm{b}} & 32.0^{\mathrm{b}} & 29.0^{\mathrm{a}} & 31.0 & 23.2-39.0 & 0.30 & 11 \\ \mathbf{1 8 : 1} \text { cis-9 } & 19.2 & 18.6 & 19.8 & 18.6 & 18.4 & 18.7^{\mathrm{ab}} & 17.7^{\mathrm{a}} & 20.1^{\mathrm{b}} & 19.2^{\mathrm{ab}} & 18.9 & 13.1-30.8 & 0.29 & 18 \\ \mathbf{1 8 : 1} \text { trans-11 } & 1.55 & 1.49 & 1.57 & 1.54 & 1.45 & 1.20^{\mathrm{a}} & 1.71^{\mathrm{b}} & 1.94^{\mathrm{c}} & 1.23^{\mathrm{a}} & 1.52 & 0.89-2.97 & 0.04 & 28 \\ \mathbf{1 8 : 2} \mathbf{n}-\mathbf{6} & 1.69 & 1.66 & 1.68 & 1.67 & 1.68 & 1.58^{\mathrm{ab}} & 1.80^{\mathrm{bc}} & 1.51^{\mathrm{a}} & 1.81^{\mathrm{c}} & 1.68 & 0.67-3.20 & 0.03 & 20 \\ \mathbf{1 8 : 3} \mathbf{n}-\mathbf{3} & 0.44 & 0.43 & 0.45 & 0.45 & 0.40 & 0.46^{\mathrm{bc}} & 0.52^{\mathrm{c}} & 0.43^{\mathrm{b}} & 0.33^{\mathrm{a}} & 0.43 & 0.16-0.91 & 0.01 & 30 \\ \mathbf{1 8 : 2} \text { cis-9, } \text { trans-11 } & 0.42^{\mathrm{b}} & 0.38^{\mathrm{a}} & 0.44^{\mathrm{b}} & 0.36^{\mathrm{a}} & 0.41^{\mathrm{ab}} & 0.40^{\mathrm{b}} & 0.41^{\mathrm{b}} & 0.26^{\mathrm{a}} & 0.51^{\mathrm{c}} & 0.40 & 0.10-0.80 & 0.01 & 35\end{array}$

\section{Group of $\mathbf{F A}^{1}$}

\begin{tabular}{llllllllllllll} 
C4-14 & 25.6 & 25.6 & $24.8^{\mathrm{a}}$ & $25.5^{\mathrm{ab}}$ & $26.5^{\mathrm{b}}$ & $25.9^{\mathrm{ab}}$ & $25.7^{\mathrm{ab}}$ & $23.5^{\mathrm{a}}$ & $27.0^{\mathrm{b}}$ & 25.6 & $14.8-34.7$ & 0.31 & 14 \\
MUFA & 22.5 & 22.3 & 23.1 & 22.2 & 21.9 & $22.3^{\mathrm{ab}}$ & $21.2^{\mathrm{a}}$ & $23.6^{\mathrm{b}}$ & $22.6^{\mathrm{ab}}$ & 22.4 & $16.7-34.8$ & 0.28 & 15 \\
\hline BCFA & 2.49 & 2.44 & $2.53^{\mathrm{b}}$ & $2.54^{\mathrm{b}}$ & $2.32^{\mathrm{a}}$ & $2.47^{\mathrm{b}}$ & $2.60^{\mathrm{b}}$ & $2.58^{\mathrm{b}}$ & $2.22^{\mathrm{a}}$ & 2.47 & $1.45-3.31$ & 0.03 & 13 \\
PUFA n-6 & 1.98 & 1.91 & 1.94 & 1.94 & 1.95 & $1.90^{\mathrm{b}}$ & $2.12^{\mathrm{b}}$ & $1.60^{\mathrm{a}}$ & $2.13^{\mathrm{b}}$ & 1.94 & $0.69-3.91$ & 0.04 & 22 \\
PUFA n-3 & 0.56 & 0.53 & 0.56 & 0.55 & 0.52 & $0.59^{\mathrm{b}}$ & $0.66^{\mathrm{b}}$ & $0.45^{\mathrm{a}}$ & $0.46^{\mathrm{a}}$ & 0.54 & $0.16-1.10$ & 0.01 & 30
\end{tabular}

$\mathrm{a}, \mathrm{b}, \mathrm{c}, \mathrm{d}=$ means in breed and parity groups with different superscripts within a row differ at $P<0.05$, in feeding ration groups at $P<0.01, C F=$ Czech Fleckvieh, $\mathrm{H}=$ Holstein, III, VI, IX, XII = feeding rations in March, June, September, and December - see Tab. II, SEM = standard error of the mean, RSD = relative standard deviation $(\%)=[$ standard deviation/mean].100;

1 C4-14 = saturated FA, even, MUFA = monounsaturated FA, cis isomers, BCFA = branched chain FA, PUFA n-6 = polyunsaturated FA n-6, PUFA n-3 = polyunsaturated FA n-3. 
in our work. However, the differences were mostly statistically insignificant.

A more desirable FA composition was observed in cows at the beginning of lactation, i.e. between days 10 and 30. The proportions of palmitic acid and the C4-14 group were lower $(27.7 \%$ and $22.6 \%$, respectively) than during the late period of lactation; for instance, between days 211 and 240 (33.3 and $26.6 \%$, respectively). In contrast, the proportions of oleic acid (18:1 cis-9), linoleic acid (18:2 n-6), monounsaturated FA and n-6 polyunsaturated FA were higher between days 10 and 30 (23.4, 1.99, 26.5 and $2.27 \%$, respectively) than between days 211 and 240 (17.2, 1.48, 21.0 and $1.75 \%$, respectively) - data not given in the table. The proportion of linoleic acid is elevated during the early lactation, while that of RA is maximal at the end of lactation (Fig. 1).

As mentioned above, some differences in FA composition could be affected by breed, cow individuality, parity or month of lactation. Nevertheless, composition of feeding ration is the main factor determining the content of saturated and unsaturated FA (Kalac and Samkova, 2010). Within the common management of cow feeding, farmers strive to prepare balanced feeding rations (Slots et al., 2009) and only adopt changes in feed components that give rise to changes in milk fat FA composition. In our work, the lowest proportion of palmitic acid $(29.0 \%)$ was associated with the highest proportion of rape seed in the feeding ration, oleic acid proportion increased during feeding of fresh maize (up to $20.1 \%$ ), and the highest proportion of alpha-linolenic acid $(0.52 \%)$ and $n-3$ polyunsaturated FA (0.66\%) was observed after feeding of fresh lucerne.
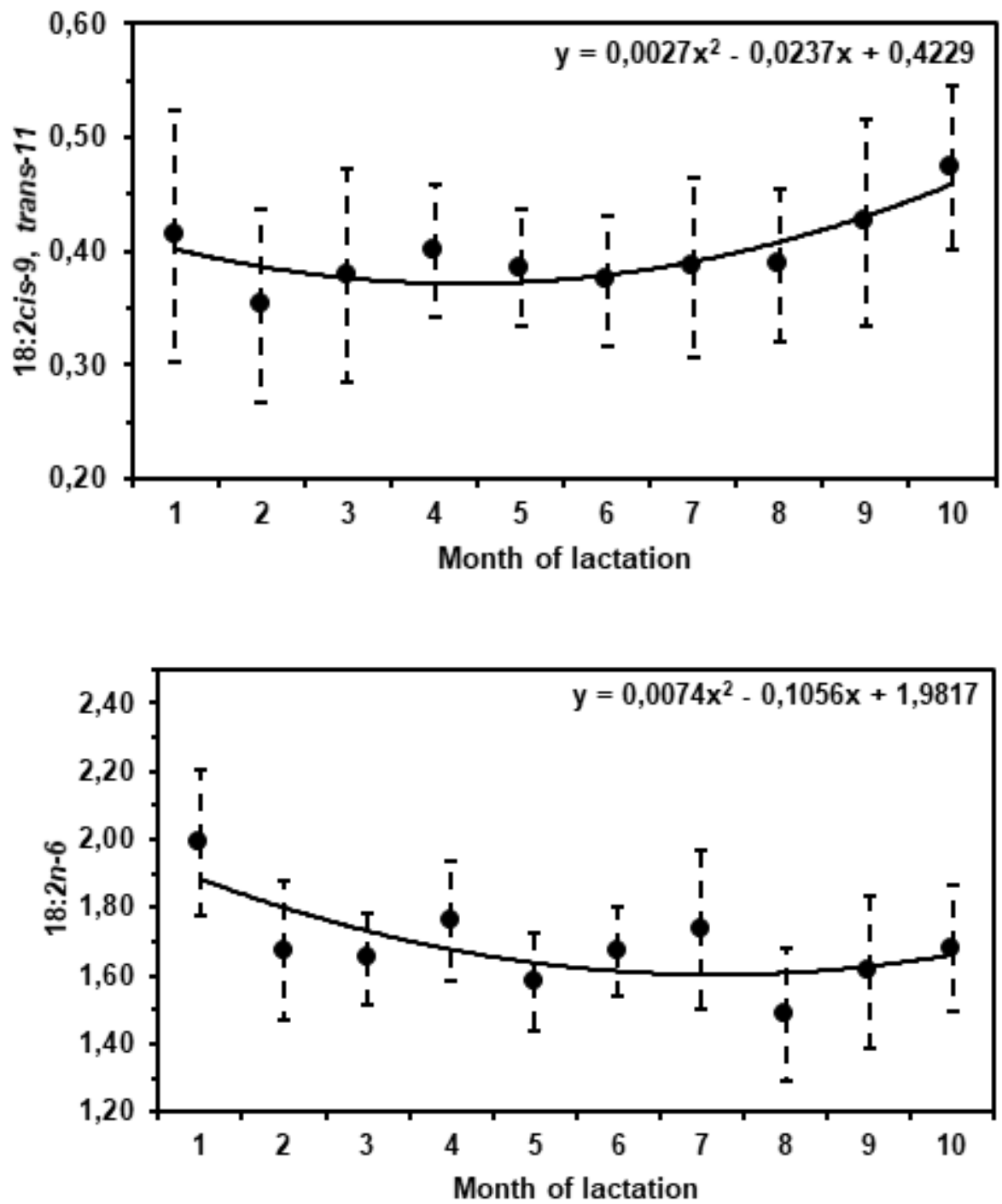

1: Proportion of 18:2 n-6, and 18:2 cis-9, trans-11 (y-axis: $g$ /100 $g$ of fatty acids) depending on month of lactation ( $x$-axis); vertical bars denote 0.95 confidence intervals. 


\section{CONCLUSION}

In conclusion, the fatty acid composition of milk fat in milked cows under common farm management conditions, particularly the presence of nutritionally desirable polyunsaturated fatty acids, is mainly affected by changes in feeding ration. The four tested factors - breed, parity, month of lactation and feeding ration - explained only a limited part of total variation. We therefore suppose that the unexplained variability is due to the individuality of cows (genetic predisposition) in their reaction to changes in feed composition. It therefore appears necessary to continue to study this topic.

\section{Acknowledgements}

Supported by the Ministry of Agriculture of the Czech Republic, project No. QJ1510336 and the Grant Agency of University of South Bohemia, project No. 002/2016/Z.

\section{REFERENCES}

BAUMAN, D. E. and GRIINARI, J. M. 2003. Nutritional regulation of milk fat synthesis. Annual Review of Nutrition, 23: 203-227.

COLLOMB, M., BUTIKOFER, U., SIEBER, R. et al. 2002. Composition of fatty acids in cow's milk fat produced in the lowlands, mountains and highlands of Switzerland using high-resolution gas chromatography. International Dairy Journal, 12(8): 649-659.

DHIMAN, T. R., NAM, S. H. and URE, A. L. 2005. Factors affecting conjugated linoleic acid content in milk and meat. Critical Reviews in Food Science and Nutrition, 45(6): 463-482.

DLG-FUTTERWERTTABELLEN. 1997. DLG-Feedingtables - Ruminants (in German). $7^{\text {th }}$ Edition. Frankfurt am Main, Germany: DLG-Verlag.

ELGERSMA, A. 2015. Grazing increases the unsaturated fatty acid concentration of milk from grass-fed cows: A review of the contributing factors, challenges and future perspectives. European Journal of Lipid Science and Technology, 117(9): 1345-1369.

GEBAUER, S. K., PSOTA, T. L. and KRIS-ETHERTON, P. M. 2007. The diversity of health effects of individual trans fatty acid isomers. Lipids, 42(9): 787-799.

CHILLIARD, Y., FERLAY, A. and DOREAU, M. 2001. Effect of different types of forages, animal fat or marine oils in cow's diet on milk fat secretion and composition, especially conjugated linoleic acid (CLA) and polyunsaturated fatty acids. Livestock Production Science, 70(1-2): 31-48.

JENSEN, R. G. 2002. The composition of bovine milk lipids: January 1995 to December 2000. Journal of Dairy Science, 85(2): 295-350.

KALAC, P. and SAMKOVA, E. 2010. The effects of feeding various forages on fatty acid composition of bovine milk fat: A review. Czech Journal of Animal Science, 55(12): 521-537.

KELSEY, J. A., CORL, B. A., COLLIER, R. J. et al. 2003. The effect of breed, parity, and stage of lactation on conjugated linoleic acid (CLA) in milk fat from dairy cows. Journal of Dairy Science, 86(8): 2588-2597.

KRAMER, J. K. G., PARODI, P. W., JENSEN, R. G. et al. 1998. Rumenic acid: A proposed common name for the major conjugated linoleic acid isomer found in natural products. Lipids, 33(8): 835-835.

LAKE, S. L., WESTON, T. R., SCHOLLJEGERDES, E. J. et al. 2007. Effects of postpartum dietary fat and body conditions core at parturition on plasma, adipose tissue, and milk fatty acid composition of lactating beef cows. Journal of Animal Science, 85(3): 717-730.

LEIBER, F., KREUZER, M., NIGG, D. et al. 2005. A study on the causes for the elevated n-3 fatty acids in cows' milk of alpine origin. Lipids, 40(2): 191-202.

MOSLEY, E. E., SHAFII, B., MOATE, P. J. et al. 2006. cis-9, trans-11 conjugated linoleic acid is synthesized directly from vaccenic acid in lactating dairy cattle. Journal of Nutrition, 136(3): 570-575.

O'DONNELL, A. M., SPATNY, K. P., VICINI, J. L. et al. 2010. Survey of the fatty acid composition of retail milk differing in label claims based on production management practices. Journal of Dairy Science, 93(5): 1918-1925.

PALMQUIST, D. L., LOCK, A. L., SHINGFIELD, K. J. et al. 2005. Biosynthesis of conjugated linoleic acid in ruminants and humans. Advances in Food and Nutrition Research, 50: 179-217.

RIEDIGER, N. D., OTHMAN, R. A., SUH, M. et al. 2009. A Systemic review of the roles of n-3 fatty acids in health and disease. Journal of the American Dietetic Association, 109(4): 668-679.

SAILAS, B. and SPENER, F. 2009. Conjugated linoleic acids as functional food: an insight into their health benefits. Nutrition $\odot$ Metabolism, 6: 36 .

SAMKOVA, E., CERTIKOVA, J., SPICKA, J. et al. 2014. Eighteen-carbon fatty acids in milk fat of Czech Fleckvieh and Holstein cows following feeding with fresh lucerne (Medicago sativa L.). Animal Science Papers and Reports, 32(3): 209-218.

SAMKOVA, E., SPICKA, J., PESEK, M. et al. 2012. Animal factors affecting fatty acid composition of cow milk fat: A review. South African Journal of Animal Science, 42(2): 83-100. 
SCHENNINK, A., HECK, J. M.L., BOVENHUIS, H. et al. 2008. Milk fatty acid unsaturation: Genetic parameters and effects of stearoyl-CoA desaturase (SCDI) and acyl CoA: diacylglycerol acyltransferase 1 (DGAT1). Journal of Dairy Science, 91(5): 2135-2143.

SCHWENDEL, B.H., WESTER, T.J., MOREL, P.C.H. et al. 2015. Invited review: Organic and conventionally produced milk - An evaluation of influence factors on milk composition. Journal of Dairy Science, 98(2): 2831-2831.

SLOTS, T., BUTLER, G., LEIFERT, C. et al. 2009. Potentials to differentiate milk composition by different feeding strategies. Journal of Dairy Science, 92(5): 2057-2066.

SOMMER, A., CERESNAKOVA, Z., FRYDRYCH, Z. et al. 1994. Nutrient requirements and tables of nutrient value of ruminant feeds. $1^{\text {st }}$ Edition. Pohorelice, Czech Republic: CZS VUVZ.

STANTON, C., LAWLESS, F., KJELLMER, G. et al. 1997. Dietary influences on bovine milk cis-9, trans-11conjugated linoleic acid content. Journal of Food Science, 62(5): 1083-1086.

STOOP, W.M., VAN ARENDONK, J.A.M., HECK, J.M.L. et al. 2008. Genetic parameters for major milk fatty acids and milk production traits of dutch Holstein-Friesians. Journal of Dairy Science, 91(1): 385-394.

VLAEMINCK, B., FIEVEZ, V., CABRITA, A.R.J. et al. 2006. Factors affecting odd- and branched-chain fatty acids in milk: A review. Animal Feed Science and Technology, 131(3-4): 389-417.

WIKING, L., THEIL, P. K., NIELSEN, J. H. et al. 2010. Effect of grazing fresh legumes or feeding silage on fatty acids and enzymes involved in the synthesis of milk fat in dairy cows. Journal of Dairy Research, 77(3): 337-342.

YANG, B., CHEN, H. Q., STANTON, C. et al. 2015. Review of the roles of conjugated linoleic acid in health and disease. Journal of Functional Foods, 15: 314-325.

Robert Kala: kalarobert@seznam.cz Eva Samková: samkova@zf.jcu.cz Jana Koubová: p.s.e.n.i.c.e@seznam.cz Lucie Hasoňová: faktotum@centrum.cz Martin Kváč: kvac@paru.cas.cz Tamara Pelikanová: tpelikan@zf.jcu.cz Jiří Špička: spicka@zf.jcu.cz Oto Hanuš: hanus.oto@seznam.cz 